\title{
ULTRASTRUCTURE OF FELINE ARTICULAR CARTILAGE IN THE POSTNATAL PERIOD
}

\author{
D. HORKÝ and F. TICHÝ \\ Department of Histology and Embryology, Faculty of Medicine, Masaryk University, 60200 Brno \\ Department of Histology and Embryology, University of Veterinary and Pharmaceutical Sciences, 61242 Brno \\ Received September 18, 1994 \\ Accepted March 30, 1995
}

\begin{abstract}
Hork ý D., F. T i c h ý: Ultrastructure of Feline Articular Cartilage in the Postnatal Period. Acta vet. Brno, 1995, 64: 63-70.

Articular cartilage was investigated in five cats of both sexes, aged 1,21 and 43 days, and in two adult cats aged 5 years. Samples for transmission electron microscopy were collected from femoral heads and processed using conventional techniques. The object of the investigations was cellular structures and intercellular matrix of the superficial, middle and deep layers, but not those of transition cells and the tide-mark region.

In the superficial layer of the samples collected from 1-, 21- and 43-day old kittens, chondrocytes were found mostly in pairs sharing a common lacuna surrounded with well formed pericellular matrix. Reticular-type nucleoli were usually present in nuclei, and scarce small mitochondria, dilated GER (granular endoplasmic reticulum) cisternae and transport vacuoles were observed in cytoplasm. Towards the middle layer, cell membranes of chondrocytes contacted the intercellular matrix. The surface of the articular cartilage was covered by a continuous and well formed chondrosynovial membrane. Areas with various appearances can be distinguished in the cartilages of adult cats. Continuous chondrosynovial membrane covered a thick layer of intercellular matrix with scarce chondrocytes in undamaged areas, while other areas showed signs of various degrees of damage.

No differences in the structure of the middle layer were found among the various age groups. Oval or spherical chondrocytes contain large nuclei and cytoplasm contains numerous GER cisternae, mitochondria, Golgi's complex, numerous smooth vesicles, sporadic lysosomes and rare centrioles and lipid droplets. Pericellular matrix had almost disappeared and cell membrane contacted closely the intercellular matrix.

The deep layer of the articular cartilage of 1-, 21- and 43-day-old kittens contained lacunae harbouring either single chondrocytes or pairs thereof arranged perpendicularly to the surface. The spindle-shaped cells were smaller and contained a lesser amount of organelles than their counterparts in the middle and the surface layers. The pattern of the intercellular matrix was similar to that of the middle layer. In addition to intact chondrocytes with a normal structure of cytoplasm and nucleus, the deep layer of the adult cartilage contained degenerated cells with large lipid droplets, glycogen deposits, disintegrated mitochondria and pyknotic nuclei.
\end{abstract}

Cat, cartilage, articular, ultrastructure

The first description of the submicroscopical structure of the articular cartilage ( $\mathrm{Z} \mathrm{e} \mathrm{l}$ a n d e r 1959) was followed by extensive studies covering almost all mammalian and several avian species. The structure has been described in rabbits ( $\mathrm{D}$ a v i e s et al. 1962), mice (S i 1 b e r g e r et al. 1976), rats (M a r k et al. 1989), dogs (W i $1 \mathrm{t} \mathrm{b}$ e r g e r and L u s t 1975), cattle (F r a n z é n 1981; H or k ý 1980, 1991a, b), swine (N a k a n o et al. 1979; B h a t $\mathrm{n}$ a g a r et al. 1981; H or k ý 1989, 1991c, 1993a, b) and goats (H o r k ý 1994b).

The hyaline articular cartilage develops from mesenchyme during skeletal ontogenesis as a component of cartilagineous blastema of the bone rudiment which changes into bone tissue during ossification. The pre-formed bone rudiment is reduced during this process which, however, does not involve the articular cartilage. Towards the joint cavity, this tissue is preserved and undergoes a series of changes during the subsequent ontogeny (B o n u c c i 1967; $\mathrm{H}$ a n a o $\mathrm{k}$ a 1976). The structural development of the articular cartilage is mostly controlled by pulling forces of muscles and ligaments and perhaps by the first fetal movements during the prenatal period, and by pressure forces associated with locomotion after birth. Another important factor is the age (see a review by H o r k ý 1991a). 
The function of the articular cartilage is predominantly mechanical and the tissue must meet the following two essential requirements to ensure correct activity: a) resist pressures, and b) provide good sliding properties of the areas of contact.The resistance to pressures results from the structure of the cartilage and arrangement of both components of the intercellular matrix (B l o e b a u m and W i l s o n 1980; H o r k ý 1980; C l a r k 1980). Chondrocytes are of negligible importance in the mechanics of articular motion, but play a key role in the synthesis of intercellular matrix which is responsible for the mechanical properties of the cartilage (B u c k w a l t e r et al. 1989 and others). Much attention has been paid to the surface layer which plays the major role in providing good sliding properties of the areas of contact (W o l f 1975; H o r k ý 1980; G i le s 1992).

Although the published data indicate that the structure of the articular cartilage has been studied in almost all mammalian species, we have not found any description of the feline cartilage and therefore we decided to complete at least partly the existing data on its morphology.

\section{Materials and Methods}

Samples of the articular cartilage for transmission electron microscopy were collected from five kittens aged 1 , 21 and 43 days and from two adult, 5-year-old cats. The sampling site was the area between ligamentum capitis femoris and trochanter major of the femoral head. Strips $1 \times 1 \times 3 \mathrm{~mm}$ were cut from the samples for further processing. The strips were immediately fixed in $400 \mathrm{mmol} / \mathrm{L}$ glutaraldehyde dissolved in $0.1 \mathrm{M}$ phosphate buffer, $\mathrm{pH} 7.4$. Then the tissue was decalcified twice for $60 \mathrm{~min}$ in $0.1 \mathrm{M}$ EDTA dissolved in $400 \mathrm{mmol} / \mathrm{L}$ glutaraldehyde, $\mathrm{pH} 7.2$ and subsequently left in the decalcifying solution overnight. After four 30-min washings in $0.1 \mathrm{M}$ phosphate buffer, $\mathrm{pH}$ 7.4, the strips were fixed twice in $40 \mathrm{mmol} / \mathrm{L} \mathrm{OsO}_{4}$ in phosphate buffer, $\mathrm{pH}$ 7.4. Conventional methods were used for dehydration, immersion and embedding into Durcupan ACM. Semithin sections were prepared from the embedded samples and stained with methylene blue and Azur II for light microscopy. Ultrathin sections for electron microscopy were prepared using the ultramicrotome LKB Nova and stained with lead citrate and uranyl acetate, or with lead citrate alone. The sections were viewed and photographed with the electron microscope Tesla BS 500.

\section{Results}

Superficial, middle and deep layers were clearly distinguishable in the articular cartilage. Attention was paid to cell types in the layers, but not to transition types of chondrocytes and to the tide-mark area owing to their considerable multiformity.

Submicroscopical structure of the superficial layer

In day-old kittens, the superficial layer of the articular cartilage was formed by single chondrocytes or pairs thereof sharing a common lacuna near the surface ( Plate XXIII, Fig. 1). The single chondrocytes were markedly spindle-shaped, while those of the isogenous pairs were irregularly oval in shape. Most of the nuclei with a diameter of up to $4 \mu \mathrm{m}$ were spherical. Chromatin was arranged in a relatively thin layer close to the nuclear membrane and in several karyosomes that can be seen in the cross-sections of the nuclei. Reticular-type nucleoli with adjacent chromatin were usually present in the nuclei. Cytoplasm contained scarce small mitochondria, transport vacuoles filled with a finely granular mass, or large, dark granules (Fig. 1). Granular endoplasmic reticulum (GER) has the appearance of dilated cisternae often communicating with the perinuclear space. Numerous short cytoplasmic projections extend into the pericellular matrix. Numerous pinocytotic vesicles can be seen near the cell membrane, particularly on the side facing towards the surface (Fig. 1). No intermediary filaments were observed.

Pericellular and intercellular matrices are distinguishable in the intercellular matter. The pericellular matrix is markedly formed in the area of chondrocyte nests facing towards the surface. The matrix is formed by abundant amorphous ground substance in which aperiodic 
collagen fibrils and solitary collagen fibrils are recognisable (Fig. 1). The pericellular matrix is missing on the reverse side of chondrocytes which is contiguous to the intercellular matrix containing collagen fibrils. The latter are arranged in parallel with the chondrocyte nests, but are scattered in a random pattern below them. The layer over the chondrocytes is covered by a thin layer of intercellular matrix formed by a small amount of collagen fibrils running in parallel with the surface, and by a $0.5 \mu \mathrm{m}$-thick chondrosynovial membrane formed by aperiodic fibrils and terminations of typical collagen fibrils inserted into it.

No differences in the submicroscopical structure of the superficial layer of the articular cartilage were found between the 21- and the 43-day-old kittens and therefore it will be described in common.

Spindle-shaped and elongated chondrocytes are situated somewhat deeper in the intercellular matrix than in the day-old kittens, occurring almost exclusively as single cells forming indistinct cell nests (Fig. 2). The long axes of the spindle-shaped chondrocytes run in parallel to the surface. Light nuclei are relatively large, the arrangement of chromatin is similar to that found in the day-old kittens and cytoplasm forms only a narrow border around the nucleus. Most of mitochondria are elongated with the usual appearance and size. Numerous narrow and often branched GER cisternae contain moderately osmiophilic granular substance.Short cytoplasmic projections extend towards the surface of cartilage, but the reverse side, facing to the middle layer, is rather smooth (Fig. 2). Scarcely, autophagic vacuoles, containing glycogen and pseudomyelin formations, were seen in the cytoplasm of chondrocytes of the middle layer.

The pericellular matrix is formed only partly and most of the chondrocytes lack it entirely. Cell membranes of the majority of chondrocytes contact closely the intercellular matrix (Fig. 2). Unlike the findings in day-old kittens, the pericellular matrix forms a dense network of crossing collagen fibres running in parallel with the surface. It is only in the between-cell space, which is usually divided by a partition, where the fibrils are arched. The chondrosynovial membrane, covering the articular cartilage, has the same structure and thickness as that of the day-old kittens.

Areas with various structures can be observed in the superficial layer of the articular cartilage in the 5-year-old cats. Most of the surface is covered by a well developed chondrosynovial membrane (Plate XXIV., Fig. 3). Up to $0.1 \mu \mathrm{m}$-thick collagen fibres, scattered in the amorphous ground substance in a random pattern and forming a dense and irregular network, predominate in the underlying, several $\mu \mathrm{m}$-thick layer of the intercellular matrix. Electronoptically dense corpuscular deposits can be observed among the collagen fibres down to the depth of $1.5 \mu \mathrm{m}$.

The appearance of the rest of the surface is quite different (Fig. 4). Collagen fibres, running in parallel with the surface, are surrounded with only a small amount of the amorphous ground substance. The chondrosynovial membrane is damaged and disintegrates as do collagenous fibrils which become exposed and protrude into the articular cavity. Thus the pattern of arthrotic cartilage develops (Fig. 4). At deeper levels, the collagen fibres run in parallel with the surface.

\section{Submicroscopical structure of the middle layer}

In day-old kittens, the middle layer of the articular cartilage consists of single chondrocytes or pairs thereof situated in the intercellular matter (Plate XXV., Fig. 5).The oval chondrocytes in size of $10 \times 7 \mu \mathrm{m}$ contain oval nuclei in which chromatin accumulates into several karyosomes in a close vicinity of the nuclear membrane. Cytoplasm contains numerous giant mitochondria with the usual structure and size and GER cisterns filled with finely granular and moderately osmiophilic substance. Agranular endoplasmatic reticulum is present in the form of minute vesicles. A common finding is transport vacuoles containing a matter with 
various densities. Short cytoplasmic projections extend into the pericellular matrix. The relatively narrow cell nests are free of fibrils and contain only the amorphous ground matter (Fig. 5). In some areas, however, the fibrils extend into the proximity of cell membrane coming into a close contact with them.

In the 21- ad 43-day old kittens, the submicroscopic structure of the middle layer does not differ significantly from that of day-old kits (Plate XXV., Fig. 6). The appearance and size of chondrocytes, as well as the arrangement of chromatin in the nucleus are similar to those described in the day-old kittens. Cytoplasm shows an amplification of Golgi's complex structures (Fig. 6) and smooth vesicles. Centrioles, situated typically in the proximity of nuclei, were observed frequently.

The arrangement of the intercellular matter is different. The pericellular matrix has almost disappeared and both aperiodic and collagen fibres come into contact with cell membrane (Fig. 6).

The middle layer of the articular cartilage of adult cats contains single chondrocytes or groups of 3 to 4 isogenous chondrocytes arranged perpendicularly to the surface of articular cartilage.These are 8- to 9- $\mu \mathrm{m}$-long chondrocytes, oval or spindle-shaped with their long axes oriented perpendicular to the surface. The nuclear shape is adjusted to that of the cells. Chromatin is arranged into several small clusters (Plate XXVI., Fig. 7). Cytoplasm contains GER cisternae, mitochondria with the usual appearance, dark corpuscles and lipid droplets. The arrangement of cell membrane does not differ from that observed in the previous stage. Owing to the absence of lacunae, the pericellular matrix has disappeared and cell membrane in a close contact to the intercellular matrix (Fig. 7).

\section{Submicroscopical structure of the deep layer}

No differences in the appearance of the deep layer of the articular cartilage were observed among the 1-. 21- and 43-day-old kittens. The size of the irregularly spindle-shaped chondrocytes, occurring alone or in pairs, is $10 \times 5-6 \mu \mathrm{m}$ and their axes are directed towards the surface (Plate XXVI., Fig. 8). Nuclei are relatively small and hyperchromatic, and contain a continuous layer of chromatin adjacent to the inner nuclear membrane. Cytoplasm contains numerous short GER cisternae, Golgi apparatus, mostly round-shaped mitochondria and numerous small smooth vesicles. Lysosomes are rather scarce (Fig. 8). The surface of cell membrane is mostly smooth with the exception of the poles where few projections extend into the pericellular matrix. The major part of the cell membrane contacts closely the intercellular matrix in which periodic collagen fibres are apparent.

The deep layer of the articular cartilage of adult cats contains a smaller number of chondrocytes varying in their appearance (Plate XXVII., Fig. 9,10). Besides cells with a structure essentially identical with that described in kittens, cells showing various degrees of damage are present (Fig. 10). Cytoplasm of the degenerated cells contains clusters of glycogen and large lipid vacuoles, and signs of nuclear damage are also evident (Fig. 10). No pericellular matrix was seen around the undamaged cells (Fig. 9). The intercellular matrix extends to the cell membrane and some collagen fibres were seen between cell membrane projections. Some pericellular matrix, containing granular substance, is present in the proximity of the cell membrane, while the appearance of the intercellular matrix is unchanged (Fig. 10).

\section{Discussion}

Similar to other mammalian species (P a l f r e y and D a v i e s 1966 ; H o r k ý 1987 , 1994ab, and others) three layers were clearly distinguishable in the feline articular cartilage in the period under study. Our findings correspond to those published by M o d l et al. (1991) as a result of a series of examinations by magnetic resonance. The definition of the three lay- 
ers in the articular cartilage conforms with our findings obtained by transmission electron microscopy (see reviews by B o z d e c $\mathrm{h}$ et al. 1990 and $\mathrm{H}$ or k ý et al. 1994ab).

The results of the investigations of the prenatal chondrosynovial membrane in cats (H o r k ý 1994a) and of the same tissue in other mammalian species in the postnatal period (cf. H o r k ý) conform with the observations published by W o l f (1975) and M c C o n a i 11 (1951). Similar conclusions were arrived at by G i l e s (1992) and K a m a l a $\mathrm{n}$ a t $\mathrm{h}$ a $\mathrm{n}$ and B r o o m (1993). Our repeated observations let us assume that bundles of aperiodic filaments, situated on or immediately below the surface cartilage, are involved in the formation of this structure without polymerization of the filaments into typical collagen fibies. Thus, a relatively thick layer develops as soon as in the prenatal period. The layer runs lower with the advancing age and provides primarily good sliding properties of the articular surfaces ( $\mathrm{S}$ w a n $\mathrm{n}$ et al. 1984).

The maturation is associated with an increase of the proportion of collagen fibres in the intercellular matrix. The fibrils are largely responsible for elasticity and resistance to pressure inherent to proteoglycans of the amorphous ground substance. This view has been fully confirmed by our finding of an increased number of collagen fibrils in the superficial layer, observed also in bovine and caprine cartilages, e.g. (H o r k ý 1994b). Our description of the pattern of the collagen fibrils in the superficial layer of the caprine articular cartilage corresponds very well to the observations published by B $\mathrm{l} \mathrm{o}$ e b a u m and W $\mathrm{i}$ i s o $\mathrm{n}$ (1980) and C l a r k (1990). In cats, the bundles were not as thick as in goats (H o r k y 1994b). They are situated at various depths underneath the surface, or below the uppermost row of chondrocytes. Their structure has also been the object of interest of other authors, because it plays an important role in the formation of the fibrous component of the cartilage (B r o o m 1986; C l a r k 1990; H e d l u n g et al. 1993) - a view which we share, too.

Here and there, fibrils of the superficial layer loosen and lesions typical of arthrosis develop (B o z d $\check{c} \mathrm{~h}$ et al. 1990). This is no unusual finding, as such damage was described, among others, by W i l t b e r g e r and L u s t (1975) and G r o n d a l e n (1974a, b) in a series of papers on canine and porcine cartilages. These authors investigated the development of the damage under various conditions including experimental surgical interventions. Recently, $\mathrm{B} \mathrm{i} \mathrm{b} \mathrm{b} \mathrm{and} \mathrm{R} \mathrm{o} \mathrm{b} \mathrm{i} \mathrm{n} \mathrm{s} \mathrm{o} \mathrm{n} \mathrm{(1993)} \mathrm{described} \mathrm{similar} \mathrm{lesions} \mathrm{in} \mathrm{the} \mathrm{articular} \mathrm{cartilage} \mathrm{after} \mathrm{the}$ reparation of an artificial damage in primates.

The middle layer of the feline articular cartilage does not substantially differ from that of other mammals of comparable age. However, the intercellular matter is arranged in a somewhat different pattern. The pericellular matrix is not distinctly developed in newborn kittens. It is particularly on the side facing towards the deep layer, where the intercellular matrix contacts closely the cell membrane of chondrocytes. The basket-like structures of collagen fibres, surrounding chondrocytes, which are typical of the bovine (H o r k y 1983) or human (H o r k ý 1980) cartilages, were not seen in feline material.

No differences in the arrangement of the deep layer were recognisable among the age groups $(1,21,43$ days, 5 years) under study. The structure of this layer is identical with that described in other mammalian species at similar phases of ontogeny (H o r k ý 1980, 1983, 1987, 1991ab, 1993, 1994ab).

The differences in the structure between young and adult individuals, so-called sprinters, and, e.g., the corresponding age groups of cattle are evident when compared with the descriptions of the superficial and the middle layers published earlier (H o r k y 1983, 1987).

\section{Ultrastruktura kloubní chrupavky kočky v postnatálním období}

Byla studována kloubní chrupavka 5 jedinců kočky obojího pohlaví v období 1,21,43 dnů po narození a 2 jedinců stáří 5 roků. Vzorky chrupavky byly odebrány pro transmisní elek- 
tronovou mikroskopii vždy $\mathrm{z}$ hlavice kyčelního kloubu a chrupavka byla zpracována obvyklým zpúsobem.

Bylo zjišsěno,že v povrchové vrstvě chrupavky věkových kategorii 1,21 a 43 dnủ po narození jsou chondrocyty uloženy nejčastěji ve dvojicích ve společné lakuně a pericelulární matrix je dobře vytvơ̌ena smě rem $\mathrm{k}$ povrchu chrupavky. Intercelulární matrix směrem ke střední vrstvě je v kontaktu s buněčný mi membránami chondrocytủ. Na povrchu artikulární chrupavky je souvislá, zřetelně vytvơ̌ená chondrosynoviální membrána. U dospělých jedincủ má povrch chrupavky rozdílný vzhled. Budto je neporušen a je kryt souvislou chondrosynoviální membránou, pod níž se vyskytuje mohutná vrstva mezibuněčné hmoty s rídce uloženými chondrocyty, nebo se objevují typické známky artrosy.

Střední vrstva u všech věkových kategorií má prakticky shodnou stavbu. Chondrocyty jsou oválného nebo okrouhlého tvaru s velkým jádrem, v cytoplasmě obsahují četné cisterny GER, mitochondrie, Golgiho komplex, četné hladké váčky a ojedinělé lysosomy a vzácně lze pozorovat centrioly a tukové kapénky. Pericelulární matrix téměr vymizela a buněčná membráńna je v těsném kontaktu s matrix intercelulární. V hluboké vrstvě kloubní chrupavky 1., 21. a 43. dne po narození jsou chondrocyty uložen̉y jednotlivě v lakunách, které jsou seřazeny do sloupcủ kolmo $\mathrm{k}$ povrchu chrupavky. Buňky jsou vřetenovitě protáhlé, menších rozměrù než v předchozích vrstvách. Mezibuněčná hmota má podobné uspơ̌ádání jako ve vrstvě střední. U dospělých jedincủ kromě intaktních chondrocytů s obvyklou strukturou cytoplasmy a jádra se vyskytují degenerované buňky, které obsahují velké tukové kapénky, depozita glykogenu, desintegrované mitochondrie a jádra se zřetelnými známkami pyknosy chromatinu.

\section{References}

BHATNAGAR R., CHRISTIAN R. G., NAKANO T., AHERNE F. X., THOMPSON J. R. 1981: Age related changes and osteochondrosis in swine articular and epiphyseal cartilage;light and electron microscopy. Can.J. Comp. Med. 45:188-195

BIBB C. A., ROBINSON P. D.1993: Histologic study of articular cartilage repair in the marmoset condyle. J.Oral Maxillofac. Surg. USA 51/10:1088-1095

BLOEBAUM R. D., WILSON A. S.1980: The morphology of the surface of articular cartilage in adult rats. J.Anat. 131/2:333-346

BONUCCI E. 1967: Fine structure of early cartilage calcification. J. Ultrastruct. Res. 20:33-45

BOYD J. S. 1977: Patterns of ossification in the feline foetus:a study of the foetal development of the skeleton of the feline using comparative methods. Index-to-Theses, 25:2-73.PhD Thesis, Glasgow University

BOZDËCH Z., HORKÝ D., JANEČEK M. 1990: Chrupavka a synoviální tkán lidského kloubu. Acta fak. med. Univ. Masaryk. Brunensis 1-150.

BROOM N.D. 1986: The collagenous architecture of articular cartilage - a synthesis of ultrastructure and mechanical function. J.Rheumatol. 13:142-152

BUCKWALTER J.A., SMITH K. C., KAZARIEN L. E., ROSENBERG L. C., UNGAR R. 1989: Articular cartilage and intervertebral disc proteoglycans differ in structure:an electron microscopic study. J.Orthop.Res.,7/1:146-151

CLARK J. M. 1990: The organization of collagen fibrils in the superficial zones of articular cartilage. J.Anat. 171:117-130

DAVIES D. V., BARNETT C. H., COCHRANE W., PALFREY A. J. 1962: Electron microscopy of articular cartilage in the young adult rabbit. Ann. rheum.Dis. 21:11-22

FRANZEN A. 1981: Variations in the composition of bovine hip articular cartilage with distance from articular surface. Biochem.J. 1951:535-543

FREEMAN M. A. R., KEMPSON G. E. 1973: Load carriage. Adult articular cartilage. In: M.A.R.Freeman, Alden Press, Oxford, Great Britain pp. 228-246

GARDNER E., O'RAHILLY R. 1968: The early development of the knee joint in staged human embryos. J.Anat.London 102:289-299

GHADIALLY F. N., ROY S. 1969: Ultrastructure of synovial joints in health and disease. Butterworths, London pp. 30-80

GHADIALLY F. N. 1982: Ultrastructural pathology of the cell and matrix. Butterworths, London, pp. 20-45

GHADIALLY F. N. 1983: Fine structure of synovial joints. Butterworths, London pp. 42-80

GILES L. G. F. 1992: The surface lamina of the articular cartilage of human zygoapophyseal joint. Anat. Rec. 233:350-356 
GRONDALEN T. 1974a: Osteochondrosis and arthrosis in pigs. I.Incidence in animals up to $120 \mathrm{~kg}$ live weight. Acta Vet. Scand. 15:1-25

GRONDALEN T. 1974b: Osteochondrosis and arthrosis in pigs. II.Incidence in breeding animals. Acta Vet.Scand. 15:26-42

GRONDALEN T. 1974c: Osteochondrosis and arthrosis in pigs.III.A comparison of the incidence in young animals of the Norwegian Landrace and Yorkshire breeds. Acta Vet.Scand. 15:43-52

GRONDALEN T. 1974d: Osteochondrosis and arthrosis in pigs. VI.Relationship to feed level and calcium, phosphorus and protein levels in the ration. Acta Vet. Scand. 15:147-169

GRONDALEN, T. 1974e: Osteochondrosis and arthrosis in pigs. VII. Relationship to joint shape and exterior conformation. Acta Vet. Scand. 15,(Suppl. 46):1-32

HANAOKA H. 1976: The fate of hypertrophic chondrocytes of the epiphyseal plate. An electron microscopic study. J. Bone Jt Surg 58: 226-229

HEDLUNG H., MENGARELLI-WIDHOLM S., REINHOLT F. P., SVENSSON O. 1993: Stereologic studies on collagen in bovine articular cartilage. APMIS, DNK 101/2:133-140

HILLS B. A. 1990: Oligolamellar nature of the articular surface. J. Rheumatol. 170: 340-356

HILLS B. A. 1989: Oligolamellar lubrication of joints by surface active phospholipid. J.Rheumatol. 16: 82-91

HORKÝ D. 1980: Submicroscopic structure of the human joint cartilage. Acta vet.Brno, 49:145-176

HORKYY D. 1983: Ontogenic development of the ultrastructure of bovine joint cartilage. Acta vet.Brno, 52:103-130

HORKÝ D. 1986: Ultrastructure of bovine articular cartilage between weeks 8 and 23 of prenatal development. Acta vet. Brno, $55: 227-246$

HORKÝ D. 1987: Submicroscopic structure of bovine articular cartilage in prenatal and early postnatal period. Acta vet. Brno, 56:3-18

HORKYY D. 1989: The ultrastructure of articular cartilage in the prenatal pig. Acta vet. Brno, 58:143-174

HORKYY D. 1991a: Submicroscopic structure of articular cartilage in human embrya six to eleven weeks old. Acta vet. Brno, 60: 15-30

HORKÝ D. 1991b: Submicroscopic structure of human articular cartilage in the period between 19 to 38 weeks after fertilization. Acta vet. Brno, 60:111-126

HORKÝ D. 1991c: The submicroscopic structure of articular cartilage in swine in the early postnatal period. Acta vet. Brno, 60: 323-334

HORKÝ D. 1993a: The submicroscopic structure of articular cartilage in the adult pig. Acta vet.Brno, 62:9-18

HORKÝ D. 1993b: The ultrastructure of articular cartilage in the prenatal domestic cat. Acta vet. Brno, 62:115-120

HORKÝ D. 1994a: Feline articular cartilage in the prenatal and early postnatal periods. A scanning electron microscopic study. Acta vet. Brno, 63:33-39

HORKÝ D. 1994b: The submicroscopic structure of caprine articular cartilage in ontogeny. Acta vet. Brno, 63:41-48

HORVATH A. 1983: Radiographical investigation of postnatal development of the hindlimb skeleton of the cat. Inaugural Dissertation, Tierarztliche FakultEt, Ludwig-Maxmilians-Universität München, $70 \mathrm{p}$.

HORVATH I. 1983: Radiographical study of the postnatal development of the forelimb skeleton of the cat. Inaugural Dissertation, TierErztliche FakultEt, Ludwig-Maximilians-Universität München, 67 p.

CHAPPUIS J., SHERMAN I. A., NEUMANN A.W. 1983: Surface tension of animal cartilage as it relates to function in joints. Ann. Biomed. Eng. 11: 435-451

JEFFERY A. K., BLUNN G. W., ARCHER C. W., BENTLEY G. 1991: Three-dimensional collagen architecture in bovine articular cartilage. J. Bone Jt. Surg. B., 73:795-801

KAMALANATHAN S., BROOM N. D. 1993: The biomechanical ambiguity of the articular surface. J. Anat. 183/3: 567-578

KIEFER G. N., SUNDBY K., McALLISTER D., HRIVE N. G., FRANK C. B., LAM T., SCHACHAR N. S. 1989: The effect of cryopreservation on the biomechanical behavior of bovine articular cartilage. J. Orthop. Res. 7:494-502

LUST G., PRONSKY W., SHERMAN D. 1972: Biochemical and ultrastructural observation in normal and degenerative canine articular cartilage. Am. J. Vet. Res. 33:2429-2440

MARK M. P., BUTLER W. T., RUCH J.V. 1989: Transient expression of a chondroitin sulfate-related epitope during cartilage histomorphogenesis in the axial skeleton of fetal rats. Develop. Biol. 133:475-489

MAROUDAS A. 1973: Physico-chemical properties of articular cartilage. In: Adult articular cartilage. Ed.: M.A.R. Freeman, Alden Press, Oxford, pp. 131-170

MCCONAILL M. A. 1951: The movements of bones and joints. The mechanical structure of articulating cartilage. J. Bone Jt. Surg. 33 B1:251-257

McCUTCHEN C. W. 1966: Boundary lubrication by synovial fluid:demonstration and posible osmotic explanation. Fed. Proc. 25:1061

MEACHIM G., STOCKWELL R. A. 1973: Adult articular cartilage. In: Adult articular cartilage. Ed.: M. A. R. Freeman, Alden Press, Oxford, pp. 20-129

MODL J. M., SERHER L. A., HAUGHTON V. M., KNEELAND J. B. 1991: Articular cartilage: Correlation of histologic zones with signal intensity at mr imaging. Radiology, USA. 181/3:853-855 
NAKANO T., AHERNE F. X., THOMPSON J. R. 1979: Changes in swine knee articular during growth. Can.J.Anim.Sci. 59:167-179

NEAME P.J., CHOI H. U., ROSENBERG L. C. 1989: The primary structure of the core protein of the small, leucine-rich proteoglycan (PG I) from bovine articular cartilage. J. Biol. Chem. 264: 8646-8653

PALFREY A. J., DAVIES D. V. 1966: The fine structure of chondrocytes. Amer. J. Anat. 100:213-228

PALMOSKI M. J., BRANDT K. D. 1984: Effects of static and cyclic compressive loading on articular cartilage plugs in vitro. Arthritis Rheum. 27:675-682

PERRIN W. R., AHERNE F. X., BOWLAND J. P., HARDIN R. T.1978: Effects of age, breed and floor type on the incidence of articular cartilage lesions in pigs. Can. J. Anim. Sci. 58: 129-138

POOLE C. A., WOTTON S. F., DUANCE V. C.1988: Localization of type XI collagen in chondrons isolated from porcine articular cartilage and rat chondrosarcoma. Histochem. J. 20/10:567-574

SHELDON H., KIMBALL F. B.1962: Studies on cartilage III. The occurrence of collagen within vacuoles of the Golgi apparatus. J. Cell Biol. 12:559-613

SCHERFT J. P., DAEMS W. Th. 1967: Single cilia in chondrocytes. J. Ultrastruct. Res. 19:546-555

SILBERGER R., SILBERGER M., VOGEL A., WETTSTEIN W.1961: Ultrastructure of articular cartilage of mice of various ages. Am. J. Anat. 109: 251-275

SILBERGER R., HASLER M., LESKER P. 1976: Ultrastructure of articular cartilage of achondroplastic mice. Acta Anat.(Basel) 96:162-175

STOCKWELL R. A., MEACHIM G. 1979: The chondrocytes. In: Adult articular cartilage. 2nd edition. Ed.: M.A.R. Freeman, London, Pittman Medical

SWANN D. A., SILVER F. H., SLAYTER H. S. 1985: The molecular structure and lubricating activity of lubricin isolated from bovine and human synovial fluids. Biochem.J. 225:195-201

WEISS C., ROSENBERG L., HELFET A. J. 1968: An ultrastructural study of normal young adult human articular cartilage. J. Bone Jt Surg. 50A:663-674

WILSMAN N. J., FARNUM C. E., HILLEY H. D., CARLSEN C. S. 1981: Ultrastructural evidence of a functional heterogeneity among physical chondrocytes in growing swine. Am. J. Vet. Res. 42: 1547-1553

WILTBERGER H., LUST G. 1975: Ultrastructure of canine articular cartilage: comparison of normal and degenerative (osteoarthritic) hip joints. Am. J. Vet. Res. 365:727-740

WOLF, J. 1975: Function of chondral membrane on surface of articular cartilage from point of wiew of its mechanical resistance. Folia Morphol. (Prague) 23:77-87

ZELANDER T. 1959: Ultrastructure of articular cartilage. Z. Zellforsch. 49: 720-738 
Horký D. et al.: Ultrastruckture...pp. 63-70.

Plate XXIII.

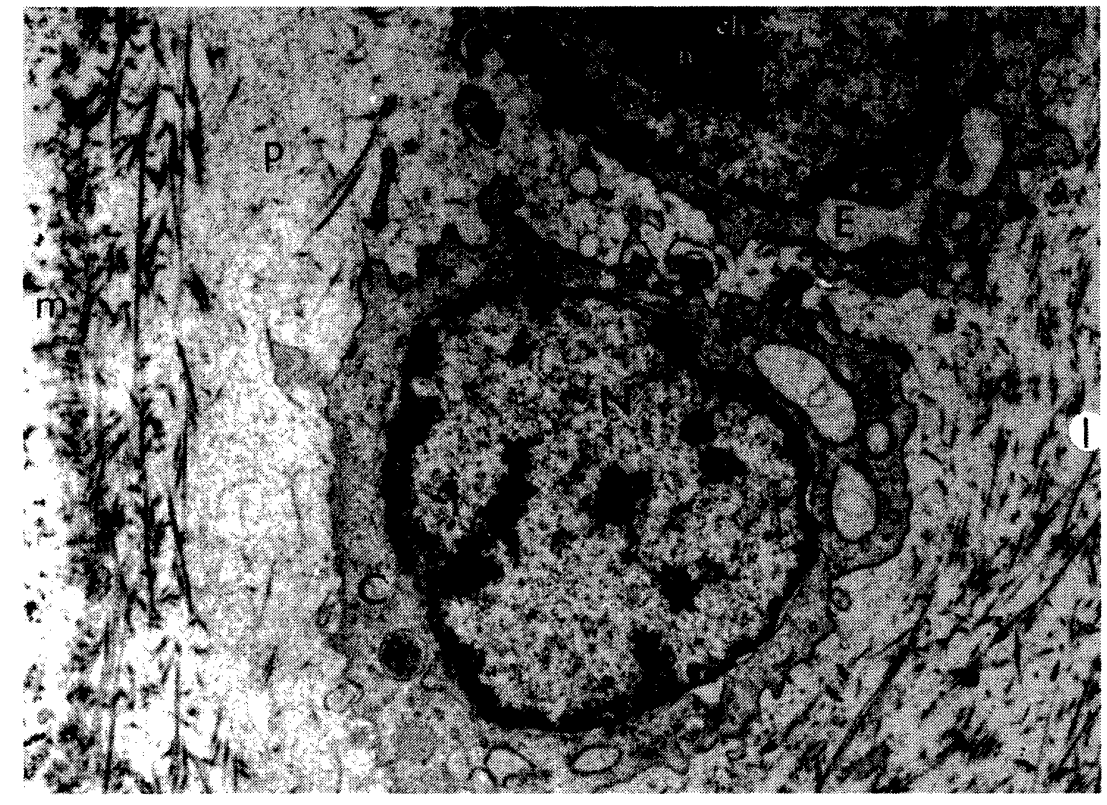

Fig. 1. Superficial layer of articular cartilage of a day-old kitten. A pair of chondrocytes (C) in a common lacuna. Nucleus $(\mathrm{N})$, nucleolus (n), perinucleolar chromatin (ch). Transport vacuoles (V), GER (E). Pericellular matrix (p), intercellular matrix (I). Chondrosynovial membrane $(\mathrm{m}) . \times 12,000$

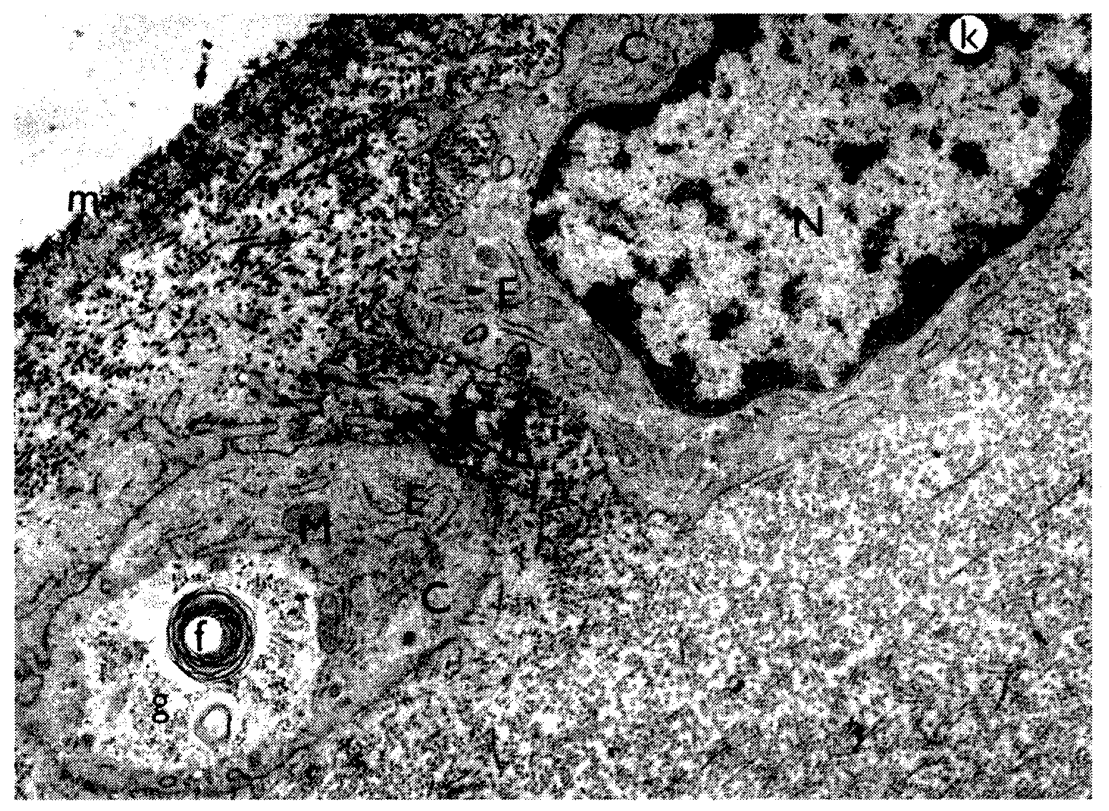

Fig. 2. Superficial layer of articular cartilage of a 43-day-old cat. Chondrocytes (C) separated by intercellular matrix (I). Nucleus $(\mathrm{N})$, karyosomes $(\mathrm{k})$, mitochondria $(\mathrm{M})$, GER (E), autophagic vacuole containing glycogen $(\mathrm{g})$, and a pseudomyelin formation (f). Thick chondrosynovial membrane (m). x 12,000 


\section{Plate XXIV.}

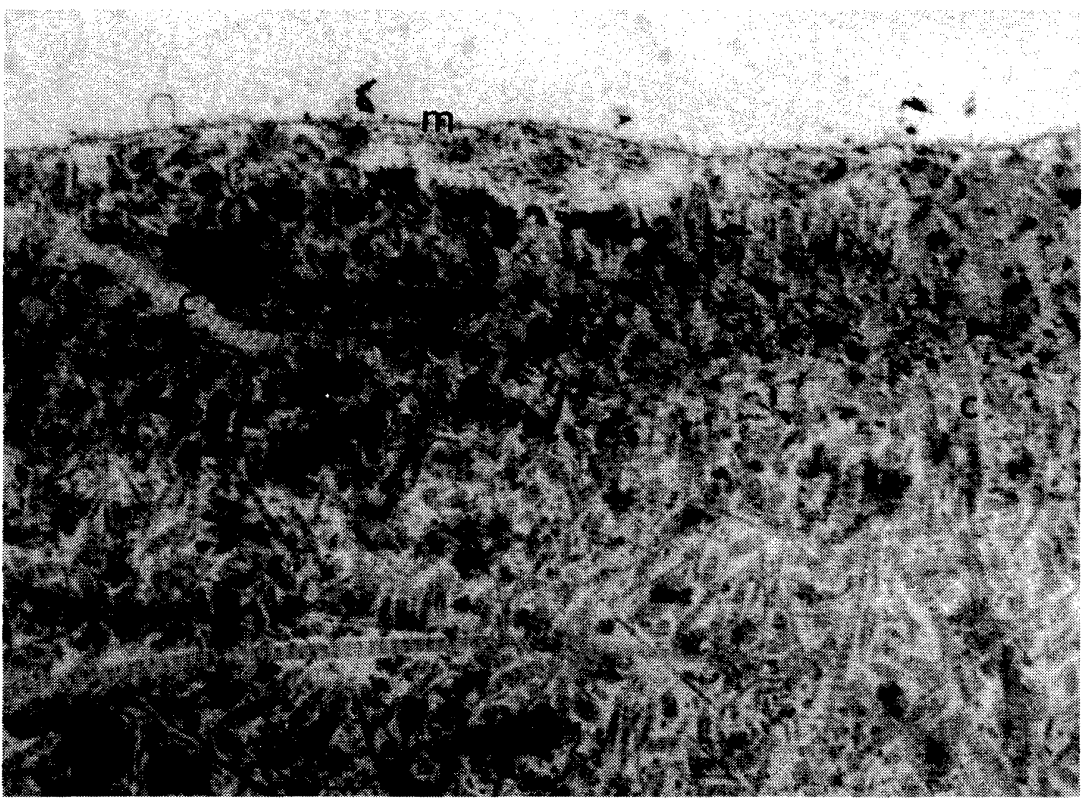

Fig. 3. Intact surface of articular cartilage of a 5-year-old cat. The superficial layer is thick and contains a small number of cells. Chondrosynovial membrane $(m)$ is thin and covers intercellular matrix containing coarse periodic collagen fibres (c). Some of the thinner fibrils point to the surface (arrow). x 16,000

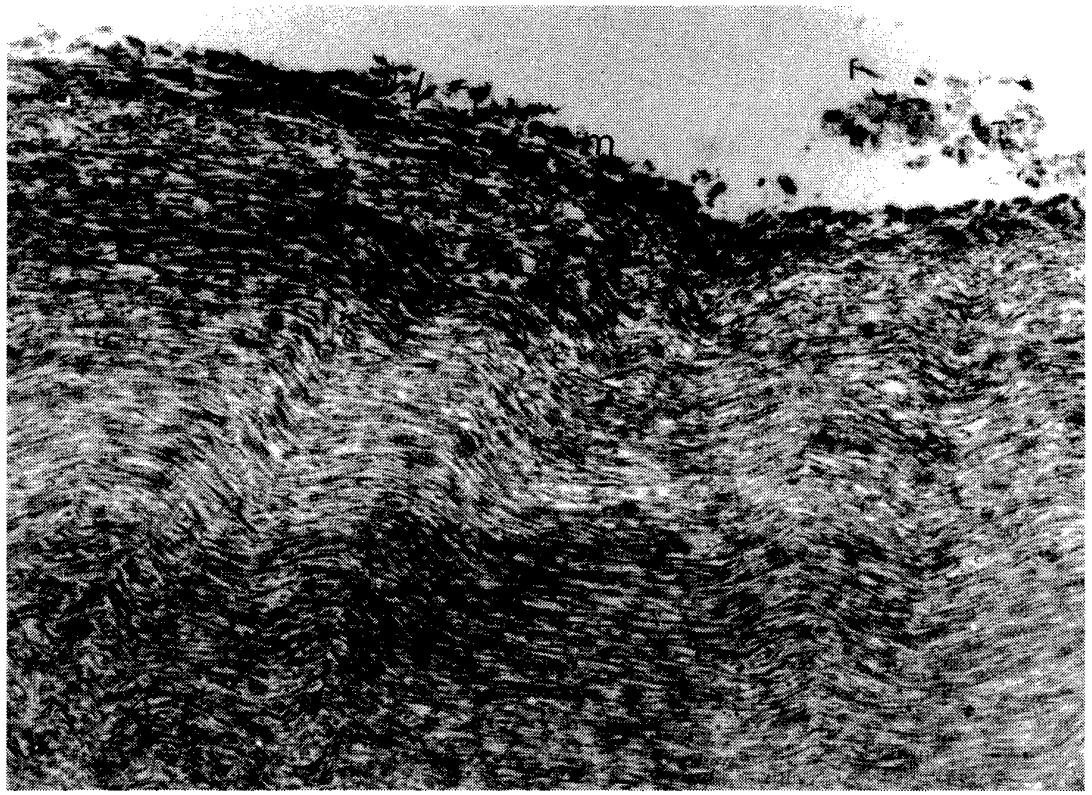

Fig. 4. Arthrotic lesions in the superficial layer of articular cartilage in a 5-year-old cat. Disintegrated chondrosynovial membrane $(\mathrm{m})$, undulated collagenous fibrils, some of which are exposed (arrow). x 12,000 


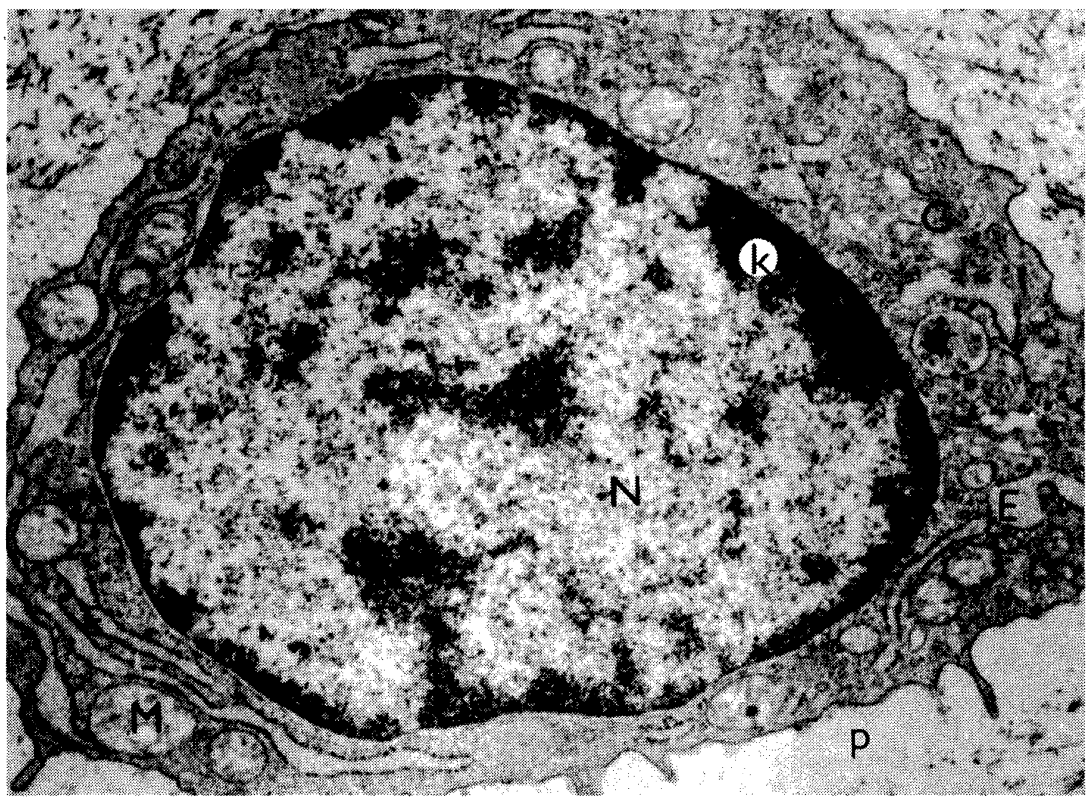

Fig. 5. Middle layer of articular cartilage of a day-old cat. Chondrocyte with a typical shape and size. Nucleus (N), karyosomes (k), mitochondria (M), transport vacuoles (V), GER cisternae (E), Golgi apparatus (G). Pericellular matrix (p) is well formed only towards the neighbouring cell in the lacuna and the middle layer. $x 16,000$

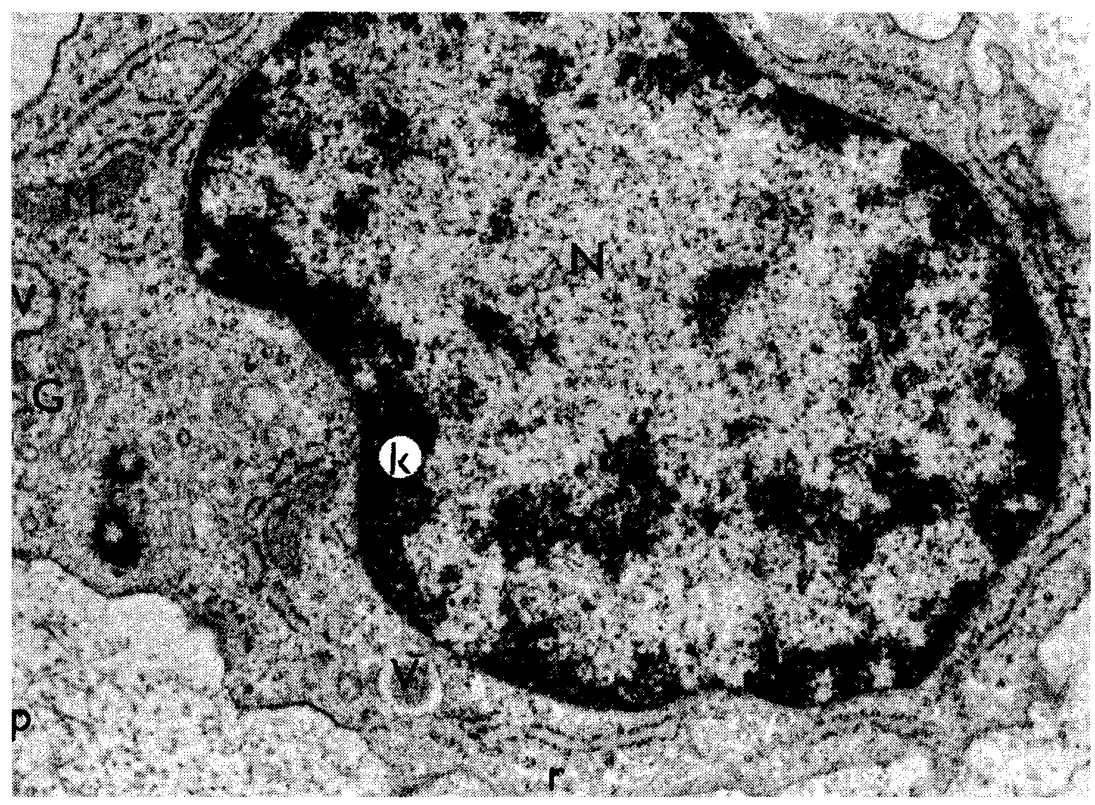

Fig. 6. Chondrocyte of the middle layer of articular cartilage of a 43-day-old cat. Nucleus (N), karyosomes (k). Mitochondria (M), transport vacuoles (V), GER (E), polysomes (r), Golgi apparatus $(G)$, centrioles $(C)$. Indistinct pericellular matrix (p). x 16,000 


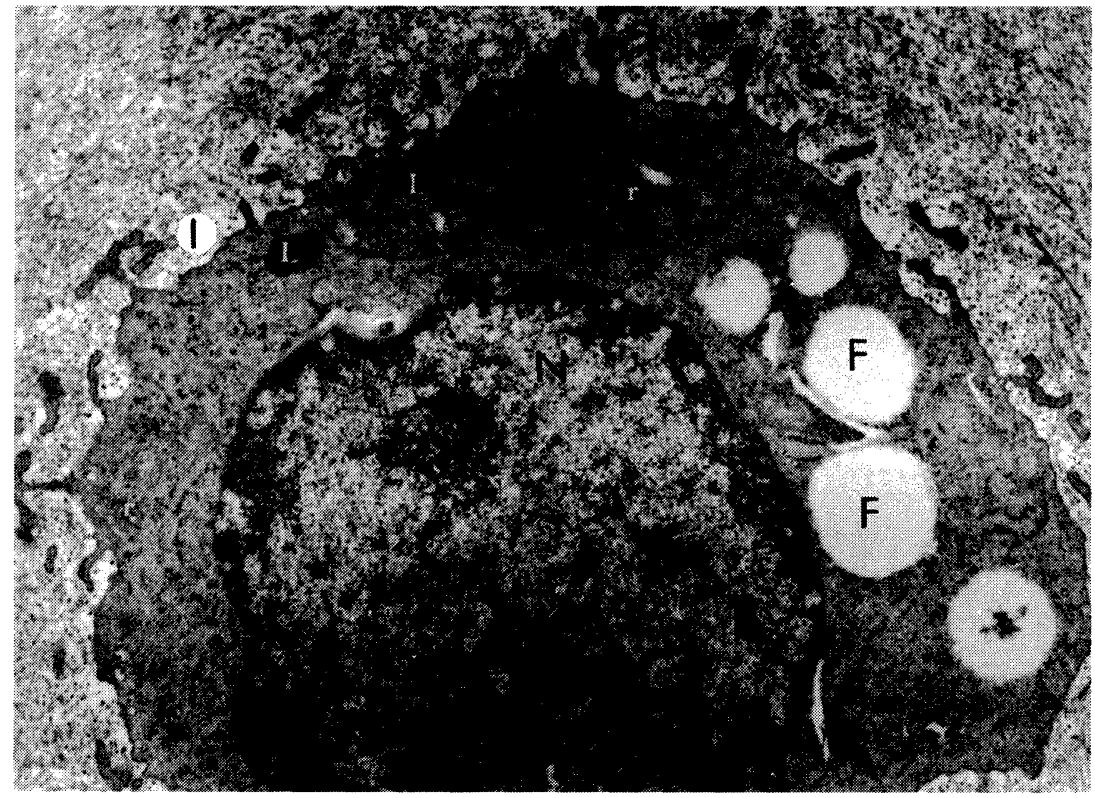

Fig. 7. Chondrocyte of the middle layer of articular cartilage of a 5-year-old cat. Nucleus (N), GER cisternae $(E)$, dark bodies $(L)$, ribosomes $(r)$, lipid droplets $(F)$. Intercellular matrix contacts closely cell membrane. x 16,000

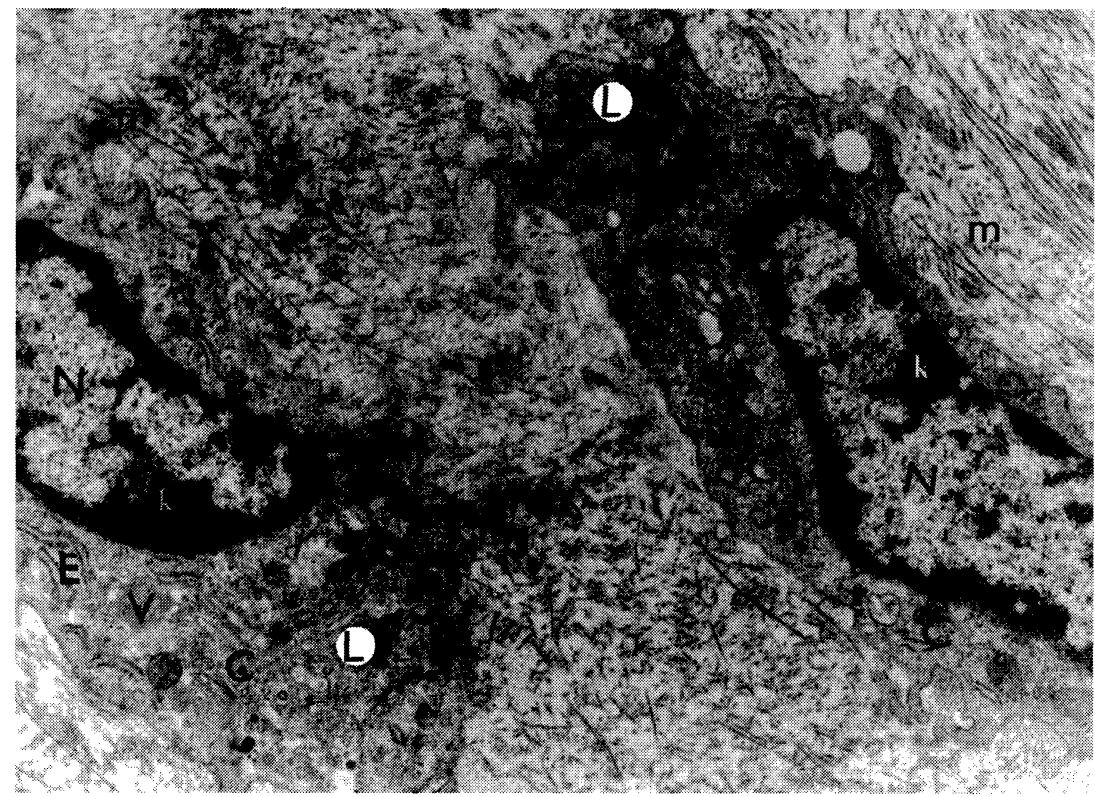

Fig. 8. Deep layer of articular cartilage of a 21-day-old cat. Single chondrocytes are arranged in columns pointing to the surface. Nucleus $(\mathrm{N})$, karyosomes $(\mathrm{k})$. Cytoplasm contains Golgi apparatus (G), GER (E), lysosomes (L) and transport vacuoles (V). Cell membrane contacts closely intercellular matrix. $\mathrm{x} 12,000$ 


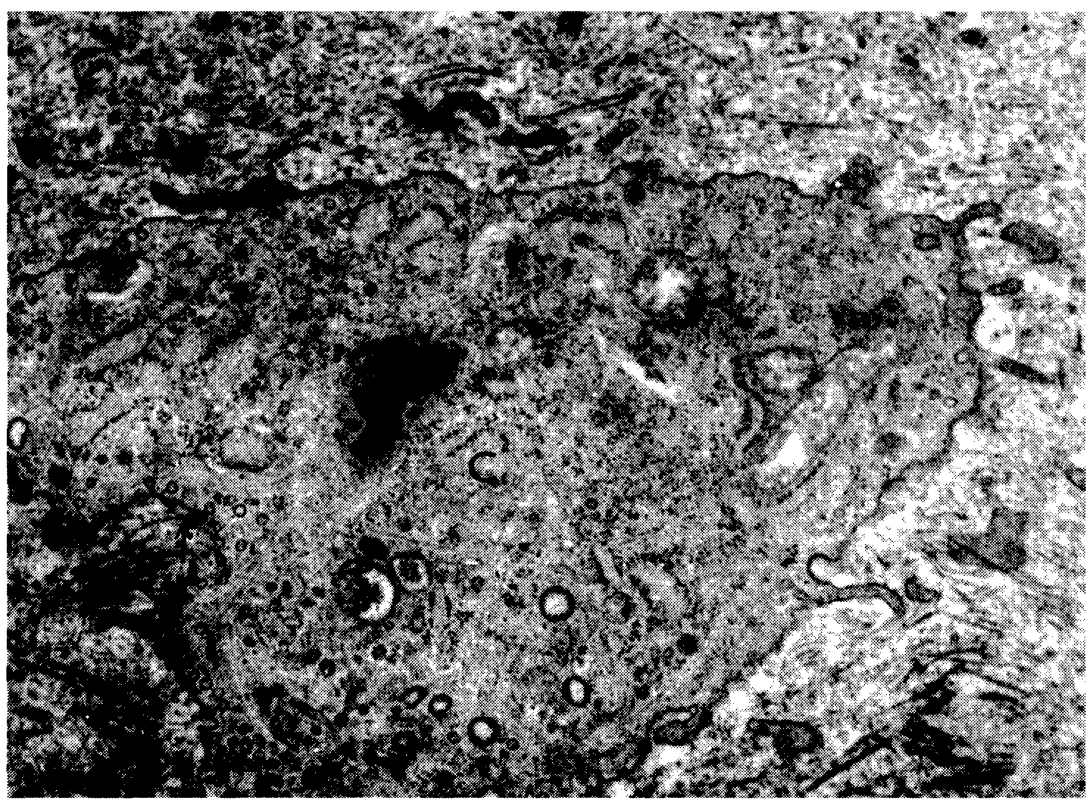

Fig. 9. Deep layer of articular cartilage of a 5-year-old cat. Chondrocyte (C) showing all signs of synthetic activity. Cytoplasm contains the usual organelles. In one of its folds, collagen fibres penetrate cell membrane into intercellular matrix (arrow). x 16,000

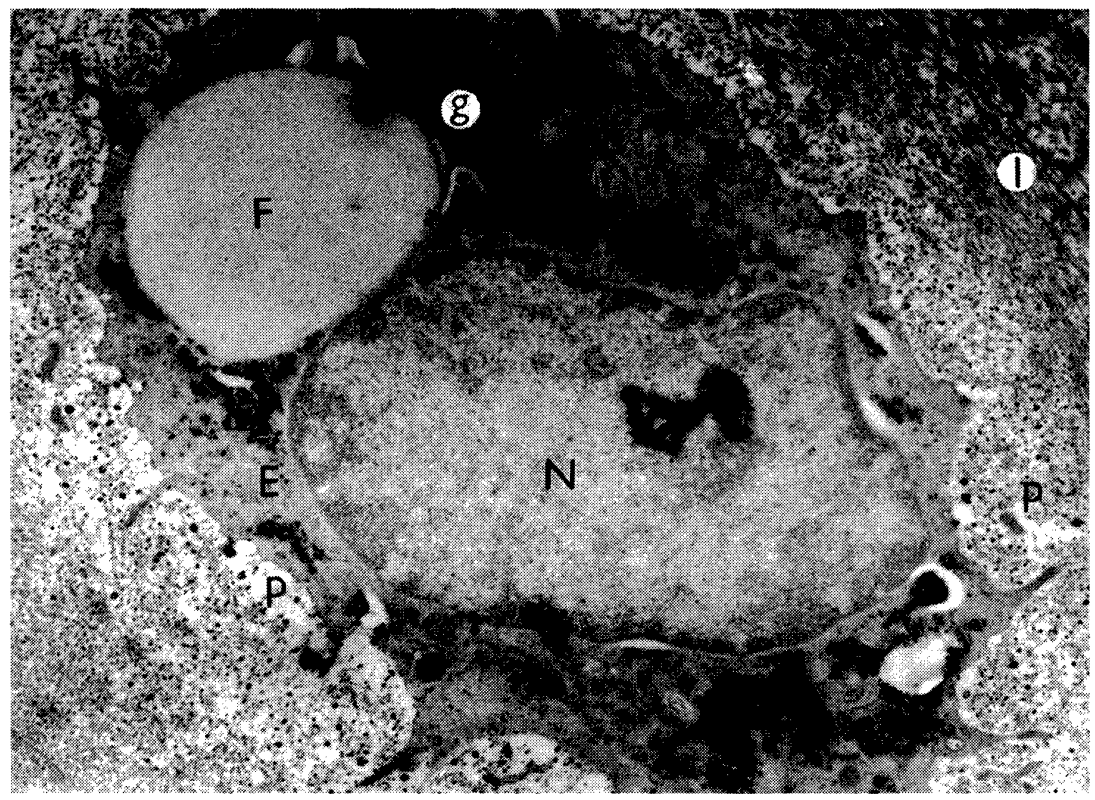

Fig. 10. Deep layer of articular cartilage of a 5-year-old cat. Chondrocyte with signs of degeneration. Nucleus $(\mathrm{N})$, glycogen deposits (g) and a large lipid vacuole (F) in cytoplasm. Rests of GER cisternae (E). Glycoprotein precipitates in pericellular matrix $(p)$ and collagen fibrils $(k)$ in intercellular matrix. x 12,000 